\title{
Prohibitin promotes apoptosis of promyelocytic leukemia induced by arsenic sulfide
}

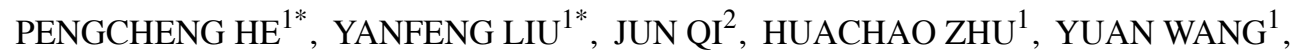 \\ JING ZHAO $^{1}$, XIAOYAN CHENG ${ }^{1}$, CHEN WANG $^{1,3}$ and MEI ZHANG ${ }^{1}$ \\ ${ }^{1}$ Department of Hematology, The First Affiliated Hospital, Xi'an Jiaotong University, Xi'an, Shaanxi; \\ ${ }^{2}$ Institute of Xi'an Blood Bank, Shaanxi Blood Center, Xi'an, Shaanxi, P.R. China; ${ }^{3}$ Pathology and Laboratory Medicine, \\ Mount Sinai Hospital, Toronto University, Toronto, ON, Canada
}

Received August 8, 2015; Accepted September 22, 2015

DOI: 10.3892/ijo.2015.3217

\begin{abstract}
Arsenic sulfide $\left(\mathrm{As}_{4} \mathrm{~S}_{4}\right)$, an oral form of arsenic agent, has been shown to have similar efficacy and safety to intravenous arsenic trioxide in the treatment of acute promyelocytic leukemia (APL). The aim of the present study was to identify proteins modulated by $\mathrm{As}_{4} \mathrm{~S}_{4}$ and to determine their involvement in the apoptotic pathway. We used comparative proteomic analysis to screen and identify the proteins that were differentially expressed with $\mathrm{As}_{4} \mathrm{~S}_{4}$ treatment. Prohibitin (PHB) was selected for its diverse role and its increased expression in the cells treated with $\mathrm{As}_{4} \mathrm{~S}_{4}$. To examine whether PHB play a functional role, two clones of PHB-knockdown and PHB-overexpression were generated by transfection of NB4-R1 with vectors containing PHB gene sequences. In comparison with parental NB4-R1 cells, PHB overexpression showed an increase in baseline apoptosis and an enhanced response in $\mathrm{As}_{4} \mathrm{~S}_{4}$-induced apoptosis. PML-RAR $\alpha$ fusion protein was found to be reduced with PHB-overexpression, and following $\mathrm{As}_{4} \mathrm{~S}_{4}$ treatment, a greater reduction of promyelocytic leukemia-retinoic acid receptor- $\alpha$ (PML-RAR $\alpha$ ) fusion protein was seen in PHB-overexpression than that in parental cells. Consistently, PHB knockdown presented with a significant reduction in $\mathrm{As}_{4} \mathrm{~S}_{4}$-induced apoptosis and a lesser degree of PML-RAR $\alpha$
\end{abstract}

Correspondence to: Professor Mei Zhang, Department of Hematology, The First Affiliated Hospital of Xi'an Jiaotong University, 277 Yanta West Road, Xi'an, Shaanxi 710061, P.R. China E-mail: zhangmei_xjtu@hotmail.com

*Contributed equally

Abbreviations: $\mathrm{As}_{4} \mathrm{~S}_{4}$, arsenic sulfide; APL, acute promyelocytic leukemia; PHB, prohibitin; ATRA, all-trans retinoic acid; PML-RAR $\alpha$, promyelocytic leukemia-retinoic acid receptor- $\alpha$

Key words: prohibitin, apoptosis, acute promyelocytic leukemia, arsenic sulfide, all-trans retinoic acid degradation. The results indicate the antitumor activity of PHB in promoting apoptosis of APL cells.

\section{Introduction}

Acute promyelocytic leukemia (APL) is characterized by specific chromosomal translocations, typically $\mathrm{t}(15 ; 17)$, which results in the formation of the promyelocytic leukemia-retinoic acid receptor- $\alpha$ (PML-RAR $\alpha$ ) fusion gene $(1,2)$. PML-RAR $\alpha$ fusion protein forms homo/heterodimers that sequestrate RXR and/or PML proteins in a large protein complex and disrupt the retinoic acid (RA) signal pathway. This specific oncogenic lesion determines characteristic cell morphology and clinical presentations, and it also determines the unique response to the treatment with all-trans retinoic acid (ATRA) or arsenic agents $(3,4)$. Both drugs have been demonstrated to target the PML/RAR $\alpha$ oncoprotein for proteasome-mediated degradation. Clinically, ATRA induces complete remissions in $~ 90 \%$ of newly diagnosed APL, but many patients eventually experience a relapse and develop ATRA-resistance $(5,6)$. Arsenic trioxide is also shown to be effective in the treatment of APL, especially in relapsed APL with ATRA-resistance $(7,8)$.

Arsenic trioxide has dual effects of inducing differentiation and apoptosis of APL cells. However, there are issues of availability and cost of arsenic trioxide that limit its general applications. The development of oral form of arsenic drug may promote its applications in APL. Arsenic sulfide $\left(\mathrm{As}_{4} \mathrm{~S}_{4}\right)$, also known as realgar, is an oral arsenic formulation. This oral arsenic drug has been shown to have similar effect and safety to intravenous arsenic trioxide in the treatment of newly diagnosed and relapsed/refractory APL or ATRA-resistance (9). The therapeutic action of $\mathrm{As}_{4} \mathrm{~S}_{4}$ is closely associated with its function of inducing apoptosis. Although it is known that $\mathrm{As}_{4} \mathrm{~S}_{4}$ induces cell apoptosis through degrading PML-RAR $\alpha$ fusion protein (10), the definitive molecular mechanisms of action of $\mathrm{As}_{4} \mathrm{~S}_{4}$ remain unclear and require further investigations.

In the present study, we used a comparative proteomic approach to screen and identify proteins that are differentially expressed in APL cells induced by $\mathrm{As}_{4} \mathrm{~S}_{4}$. By using two-dimensional gel electrophoresis (2-DE) followed by a matrix-assisted laser desorption/ionization-time-of-flight mass spectrometry (MALDI-TOF MS) analysis, we identified prohibitin (PHB) 
among the differentially expressed proteins. PHB was significantly upregulated in ATRA-resistance APL cells (NB4-R1) by $\mathrm{As}_{4} \mathrm{~S}_{4}$ treatment. Further studies of PHB-knockdown and PHB-overexpression indicate a functional role of $\mathrm{PHB}$ in $\mathrm{As}_{4} \mathrm{~S}_{4}$-induced apoptosis of NB4-R1 cells.

\section{Materials and methods}

Cell culture. The ATRA-resistance human APL cell line (NB4-R1), received from Shanghai Institute of Hematology, (Shanghai, China) was maintained in cultures with RPMI-1640 medium (Gibco-BRL, Carlsbad, CA, USA) supplemented with $10 \%$ heated-inactivated fetal bovine serum (FBS) at $37^{\circ} \mathrm{C}$ in a humidified incubator containing $5 \% \mathrm{CO}_{2}$.

Cell viability assay. Cytotoxicity of $\mathrm{As}_{4} \mathrm{~S}_{4}$ (Xi'an Traditional Chinese Drug Company, Xi'an, China) was assessed by using MTT assay (Sigma, St. Louis, MO, USA) (11). The absorbance was measured at $570 \mathrm{~nm}$ using a universal microplate reader (Model ELx800; BioTek Instruments, Inc., Winooski, VT, USA). Experiments were performed in triplicate.

Apoptosis evaluation. Transmission electron microscopy (TEM) and flow cytometric analysis (FCM) were performed to evaluate cell apoptosis. After the various treatments, the cell samples were examined under a JEM-100SX electron microscope (JEOL, Ltd., Tokyo, Japan) and were analyzed in a FACSCalibur flow cytometer (Becton-Dickinson, San Jose, CA, USA) and CellQuest software, respectively. All experiments were performed in triplicate.

2-DE and image analysis. Total cellular proteins were prepared from NB4-R1 cells before and after $\mathrm{As}_{4} \mathrm{~S}_{4}$ treatment. Protein extraction was performed by sonication in a sample buffer (SB) containing $40 \mathrm{mM}$ Tris base, $8 \mathrm{M}$ urea, $2 \mathrm{M}$ thiourea, 4\% (w/v) CHAPS, $1 \%(\mathrm{w} / \mathrm{v})$ dithiothreitol (DTT), $1 \mathrm{mM}$ EDTA and protease inhibitor cocktail (Roche Diagnostics Ltd., Mannheim, Germany). For nuclei enrichment cells were dissolved in $200 \mu \mathrm{l}$ of lysis buffer $[10 \mathrm{mM}$ HEPES, $1.5 \mathrm{mM} \mathrm{MgCl}_{2}, 10 \mathrm{mM} \mathrm{KCl,} 0.5 \mathrm{mM}$ DTT, in the presence of protease inhibitor cocktail (Sigma), $20 \mathrm{ng} / \mu 1$ DNase and $20 \mathrm{ng} / \mu \mathrm{l}$ RNase] and incubated on ice for $30 \mathrm{~min}$. After incubation, NP-40 (Roche) was added at final concentration of $0.5 \%(\mathrm{v} / \mathrm{v})$. After centrifugation at $14,000 \mathrm{rpm}$ for $30 \mathrm{~min}$ at $4^{\circ} \mathrm{C}$, the supernatant was used for analysis with the protein concentration determined by the Bradford method with a commercial Bradford reagent (Bio-Rad Laboratories, Hercules, CA, USA) (12).

2-DE was performed as described by Görg et al (13). Briefly, $140 \mu \mathrm{g}$ of protein (for silver nitrate staining gels) or $1.4 \mathrm{mg}$ of protein (for coomassie brilliant blue staining gels) was diluted to $350 \mu \mathrm{l}$ with rehydration solution and applied onto $18 \mathrm{~cm}$ ( $\mathrm{pH} 3-10)$ not linear immobilized $\mathrm{pH}$ gradient dry strip (Amersham Pharmacia Biotech, Uppsala, Sweden). After the strips were rehydrated, isoelectric focusing was performed in the IPGphor system (Amersham Pharmacia Biotech) according to the manufacturer's protocol (14). The strips were equilibrated for $15 \mathrm{~min}$ in a solution containing $6 \mathrm{M}$ urea, 2\% (w/v) SDS, 20 mM DTT, 30\% (w/v) glycerol and $50 \mathrm{mM}$ Tris- $\mathrm{HCl}(\mathrm{pH} 8.8)$. A second equilibration was also carried out for $15 \mathrm{~min}$ in the same solution except for DTT replaced by $100 \mathrm{mM}$ iodoacetamide. The second dimension was performed on $13 \%$ SDS-polyacrylamide gradient gels using the PROTEAN XI Cell (Bio-Rad Laboratories) at $20 \mathrm{~mA} / \mathrm{gel}$ for $40 \mathrm{~min}$.

Silver nitrate staining according to the protocol of Lelong et al (15), and coomassie brilliant blue R-250 (0.05\% brilliant blue) was used for the analytical and preparative gels. The 2-DE images were acquired using Image scanner (Amersham Pharmacia Biotech). Gel images were analyzed by the ImageMaster 2D Platinum software (Amersham Pharmacia Biotech). Spot detection and normalization were performed by the automated software tools.

MALDI-TOF MS and MALDI-TOF MS/MS analysis. Differentially expressed spots were manually excised from 2-DE gels. Gel pieces were destained and digestion. In-gel digestion was done according to the protocol of Granvogl et al (16).

MALDI-TOFMS analysis was performed on a Bruker REFLEX III MALDI-TOF-MS (Bruker-Franzen, Bremen, Germany). Peptides were desalted by C18 ZipTips (Millipore, Billerica, MA, USA) and co-crystallized with a solution of $0.5 \mathrm{mg} / \mathrm{ml} \alpha$-cyano-4-hydroxycinnamic acid dissolved in acetonitrile/0.1\% (v/v) trifluoroacetic acid (TFA) in $\mathrm{H}_{2} \mathrm{O}$ (1:1) pre-spotted with a thin layer of $10 \mathrm{mg} / \mathrm{ml} \alpha$-cyano-4hydroxycinnamic acid dissolved in ethanol/acetonitrile/0.1\% (v/v) TFA in $\mathrm{H}_{2} \mathrm{O}$ (49.5:49.5:1). Monoisotopic peptide masses were used to search the database, allowing a peptide mass accuracy of $0.3 \mathrm{Da}$ and one partial cleavage. The proteins were identified by peptide mass fingerprinting (PMF) searching, against the Swiss-Prot databases and NCBI databases, using the search program Mascot (http://www.matrixscience.com).

The protein spots which were not identified by MALDITOF-MS were analyzed by MALDI-TOF MS/MS. MALDI-TOF MS/MS analysis was performed in LIFT mode. Precursor ions were selected manually. MS/MS spectra were acquired with a minimum of 4000 and a maximum of 8000 laser shots using the instrument calibration file. The precursor mass window was set automatically after the precursor ion selection. Spectra baseline subtraction, smoothing (SavitskyGolay) and centroiding was performed by FlexAnalysis software (version 3.0; Bruker Daltonik GmbH, Bremen, Germany).

Western blot analysis. Cell protein extracts were prepared following standard procedures. The protein samples $(\sim 20 \mathrm{mg})$ were separated by SDS-PAGE. After SDS-PAGE, proteins were transferred to nitrocellulose membranes (Invitrogen, Carlsbad, CA, USA). The filters were washed, blocked with 5\% bovine serum albumin (BSA) in Tris-buffered saline $(25 \mathrm{mM}$ Tris, $\mathrm{pH} 7.4,136 \mathrm{mM} \mathrm{NaCl}, 2.6 \mathrm{mM} \mathrm{KCl}$ and $0.5 \%$ Tween-20) for $1 \mathrm{~h}$, and incubated overnight with mouse anti-PHB antibody diluted to 1:700 (Abcam, Cambridge, MA, USA) at room temperature. After washing three times with TBST buffer, the membranes were incubated with the secondary HRP-conjugated goat anti-mouse IgG Ab (Santa Cruz Biotechnology, Santa Cruz, CA, USA) at 1:10,000 dilution. Mouse anti-GAPDH antibody (Santa Cruz Biotechnology) was used to ensure equal loading of samples. 
Quantitative real-time PCR ( $q$ RT-PCR). The total RNA from cells was isolated with TRIzol (Life Technologies, Rockvile, MD, USA) and reverse-transcribed to cDNA by using the PrimeScript ${ }^{\text {TM }}$ RT reagent kit (Takara Bio, Dalian, China). The cDNA was studied using a CFX96 real-time PCR system (Bio-Rad Laboratories) with SYBR-Green PCR Master Mix (Takara) to determine the transcriptional expression of PHB gene. PCR products were electrophoresed on $1.5 \%$ agarose gels. The GAPDH was used for normalization, relative gene expression was calculated by the $2^{-\Delta \Delta \mathrm{Ct}}$ method.

Knockdown and overexpressing of $P H B$. Lentiviral vectormediated shRNA targeting human PHB mRNA (named pGCSIL-GFP-PHB) was previously described (17). The target sequences on the human PHB gene (GeneBank accession number NM_002634) for RNAi were designed using an internet application system as follows: 5'-GAGTTCACAGA AGCGGTGGAA3'. A shRNA which had no significant homology to any known human gene (5'-TTCTCCGAACGT GTCACGT-3') was used as a negative control. Oligonucleotides were ligated into the AgeI and EcoRI sites of pGCSIL-GFP vector (BD Biosciences, San Jose, CA, USA) to generate a pGCSIL-GFP-PHB, which was then transformed into E. coli. Positive recombinant clones were selected by PCR (upstream primer: 5'-CCTATTTCCCATGATTCCTTCATA-3'; downstream primer: 5'-GTAATACGGTTATCCACGCG-3') and DNA sequencing. The recombinant lentivirus vector was produced by co-transfecting $293 \mathrm{~T}$ cells with the lentivirus expression plasmid and packaging plasmids (pHelper 1.0 and pHelper 2.0) with Lipofectamine 2000 (Invitrogen). Infectious lentivirus vector was harvested at $48 \mathrm{~h}$ post-transfection and then concentrated. The infectious titer was determined by the GFP-tagged positive rate in 293T cells. NB4-R1 cells were cultured at a density of $6 \times 10 \%$ well in 6-well plates and infected with lentivirus in RPMI-1640 media containing 10\% FBS and $8 \mu \mathrm{g} / \mathrm{ml}$ of polybrene (Sigma), at the multiplicity of infection (MOI) 20, according to the pre-experimental results. After $48 \mathrm{~h}$ of culture, the transduction efficiency was ascertained on the basis of GFP expression under a fluorescence microscope. The knockdown efficiency of PHB was analyzed by real-time quantitative PCR and western blot analysis. NB4-R1 cells transfected with vector containing pGCSIL-GFP-PHB were designated as PHB-knockdown (KD).

The PHB gene overexpression vector (named pEGFPN1-3FLAG-PHB) was also established. Briefly, the cDNA fragment of PHB was amplified using a PCR-based approach (upstream primer: 5'-CCGCTCGAGATGGCTGCCAAAGT GTTTG; downstream primer: 5'-GGGGTACCGTCTGGGG CAGCTGGAGGAG) from a cDNA library. The PCR fragment of confirmed sequences was ligated into the $\mathrm{XhoI}$ and $K p n I$ sites of overexpression vector pEGFP-N1-3FLAG (BD Biosciences). The resultant construct, pEGFP-N1-3FLAG$\mathrm{PHB}$, was transformed into $E$. coli. Positive recombinant clones were selected by PCR and DNA sequencing (upstream primer: 5'-CGCAAATGGGCGGTAGGCGTG-3'; downstream primer: 5'-CGTCGCCGTCCAGCTCGACCAG-3'). The expression of PHB was analyzed by real-time quantitative PCR and western blot analysis. The NB4-R1 cell clone transfected with the vector containing pEGFP-N1-3FLAG-PHB were designated as PHB-overexpression (OE).

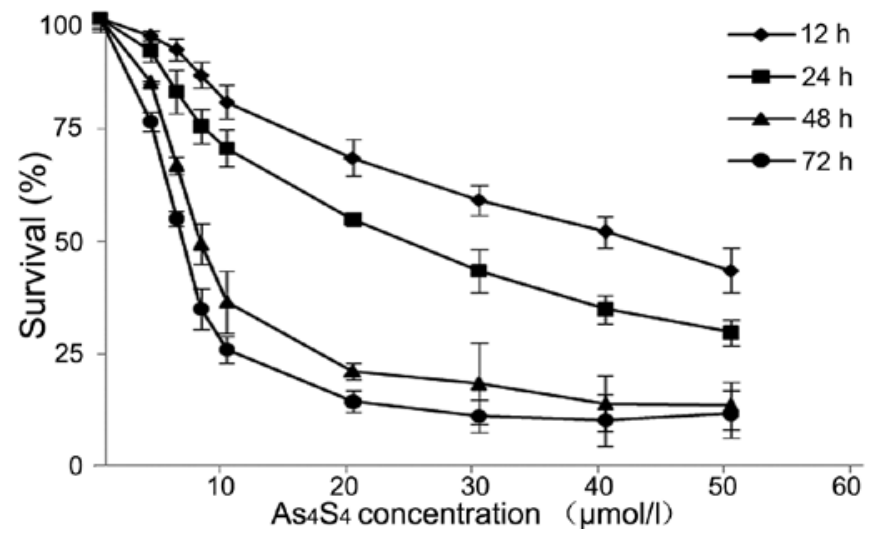

Figure 1. Dose- and time-dependent inhibition of NB4-R1 cells as determined by the MTT assay. The results are expressed as a percentage of viable cells compared with control cells. Each value represents the mean \pm SD of triplicate experiments.

Statistical analysis. The results are expressed as mean \pm standard deviation values of three experiments performed in duplicate. Statistical analysis was carried out by one-way analysis of variance. Newman-Keuls test was used for the identification of statistically significant differences in spot volume percentage among different samples. Differences were considered statistically significant when $\mathrm{P}<0.05$.

\section{Results}

$\mathrm{As}_{4} \mathrm{~S}_{4}$ inhibits the growth of ATRA-resistant NB4-RI cells. We started with MTT assay to evaluate the cytotoxicity of $\mathrm{As}_{4} \mathrm{~S}_{4}$ on ATRA-resistant NB4-R1 cells. The results demonstrated that $\mathrm{As}_{4} \mathrm{~S}_{4}$ inhibited the growth of NB4-R1 cells in a doseand time-dependent manner (Fig. 1). The $\mathrm{IC}_{50}$ values of $\mathrm{As}_{4} \mathrm{~S}_{4}$ were determined at $43.04 \pm 0.11 \mu \mathrm{M}$ for $12 \mathrm{~h}, 25.07 \pm 0.27 \mu \mathrm{M}$ for $24 \mathrm{~h}, 9.70 \pm 0.13 \mu \mathrm{M}$ for $48 \mathrm{~h}$ and $6.38 \pm 0.09 \mu \mathrm{M}$ for $72 \mathrm{~h}$ in culture. The concentration of $25 \mu \mathrm{M}$, the $\mathrm{IC}_{50}$ of $\mathrm{As}_{4} \mathrm{~S}_{4}$ at $24 \mathrm{~h}$, was chosen for subsequent experiments.

$\mathrm{As}_{4} \mathrm{~S}_{4}$ induces apoptosis of NB4-RI cells. $\mathrm{As}_{4} \mathrm{~S}_{4}$-induced apoptosis was assessed by using TEM and FCM analysis. The NB4-R1 cells treated with $\mathrm{As}_{4} \mathrm{~S}_{4}$ showed morphological features of cytoplasmic vacuolization, chromatin condensation, nuclear fragmentation and formation of apoptotic bodies (Fig. 2A). The apoptotic cells were quantified by FCM assay for Annexin $\mathrm{V}^{+}$cells. The percentage of apoptotic cells was significantly increased with $\mathrm{As}_{4} \mathrm{~S}_{4}$ treatment for 24 and $48 \mathrm{~h}$ (Fig. 2B).

PHB is an upregulated protein induced by $\mathrm{As}_{4} \mathrm{~S}_{4}$. We next used proteomic approaches to screen and identify proteins that were differentially expressed following $\mathrm{As}_{4} \mathrm{~S}_{4}$ treatment. The comparison of 2-DE protein profiles of NB4-R1 cells at $0 \mathrm{~h}$ with that at 24 and $48 \mathrm{~h} \mathrm{As}_{4} \mathrm{~S}_{4}$ treatment were performed, and 22 protein spots with at least a 2 -fold increase or decrease in density were selected for further analysis (Fig. 3A and B).

These spots were cut out, followed by in-gel trypsin digestion and MALDI-TOF MS analysis. The protein spots which were not identified by MALDI-TOF-MS were further 


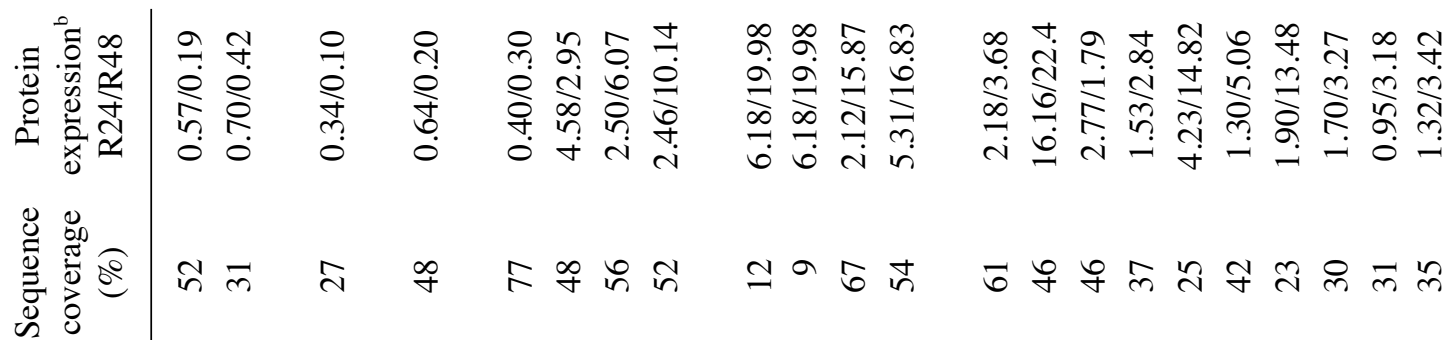

䑻|

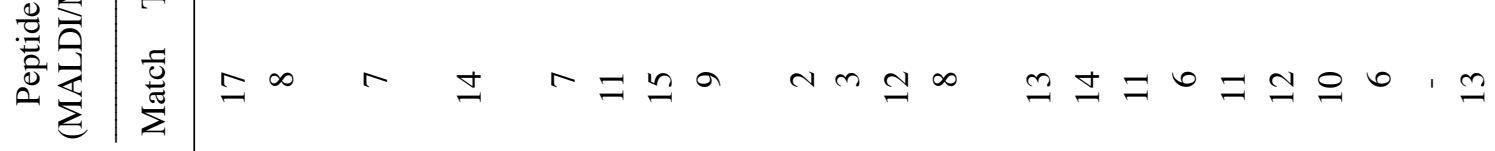

2

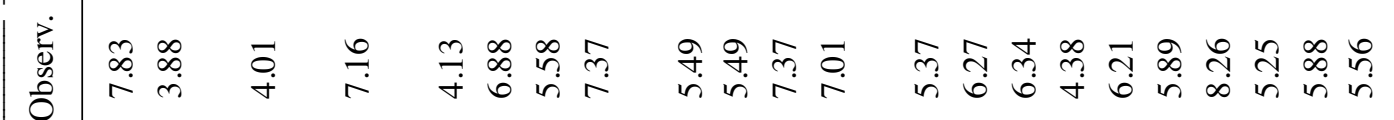

舟

苛

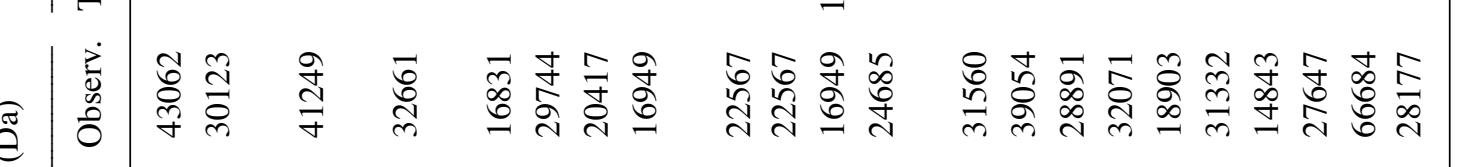

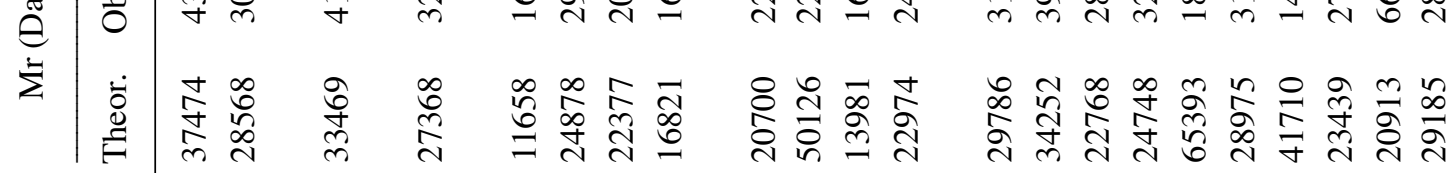

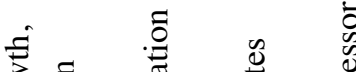
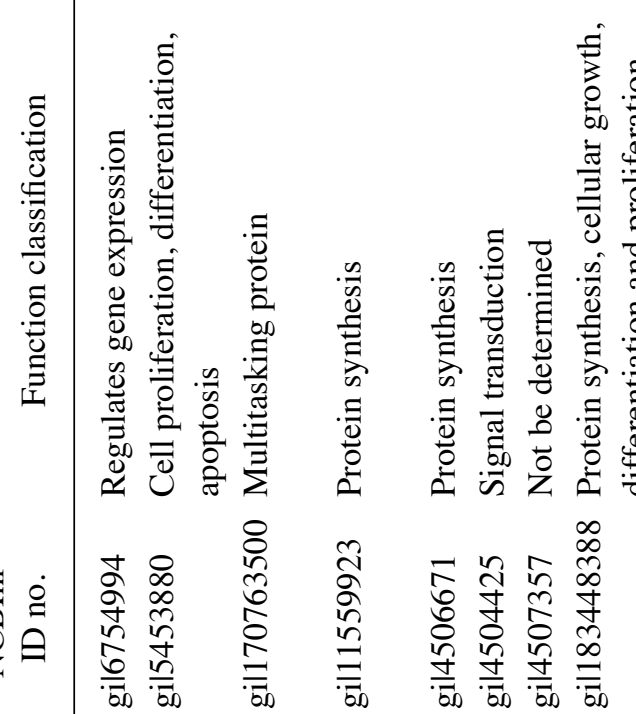

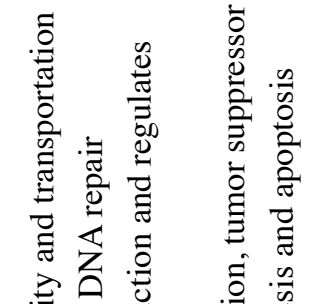

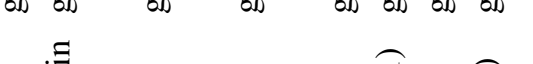

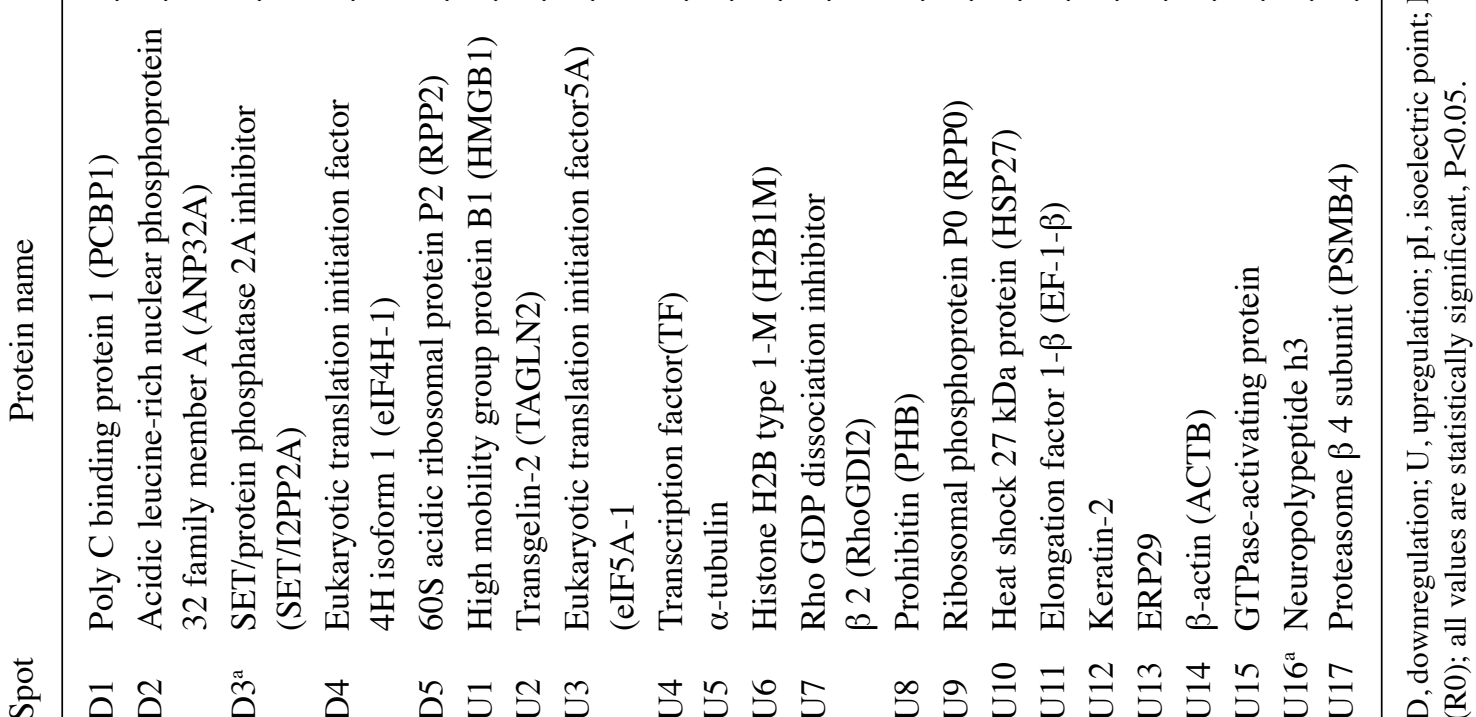



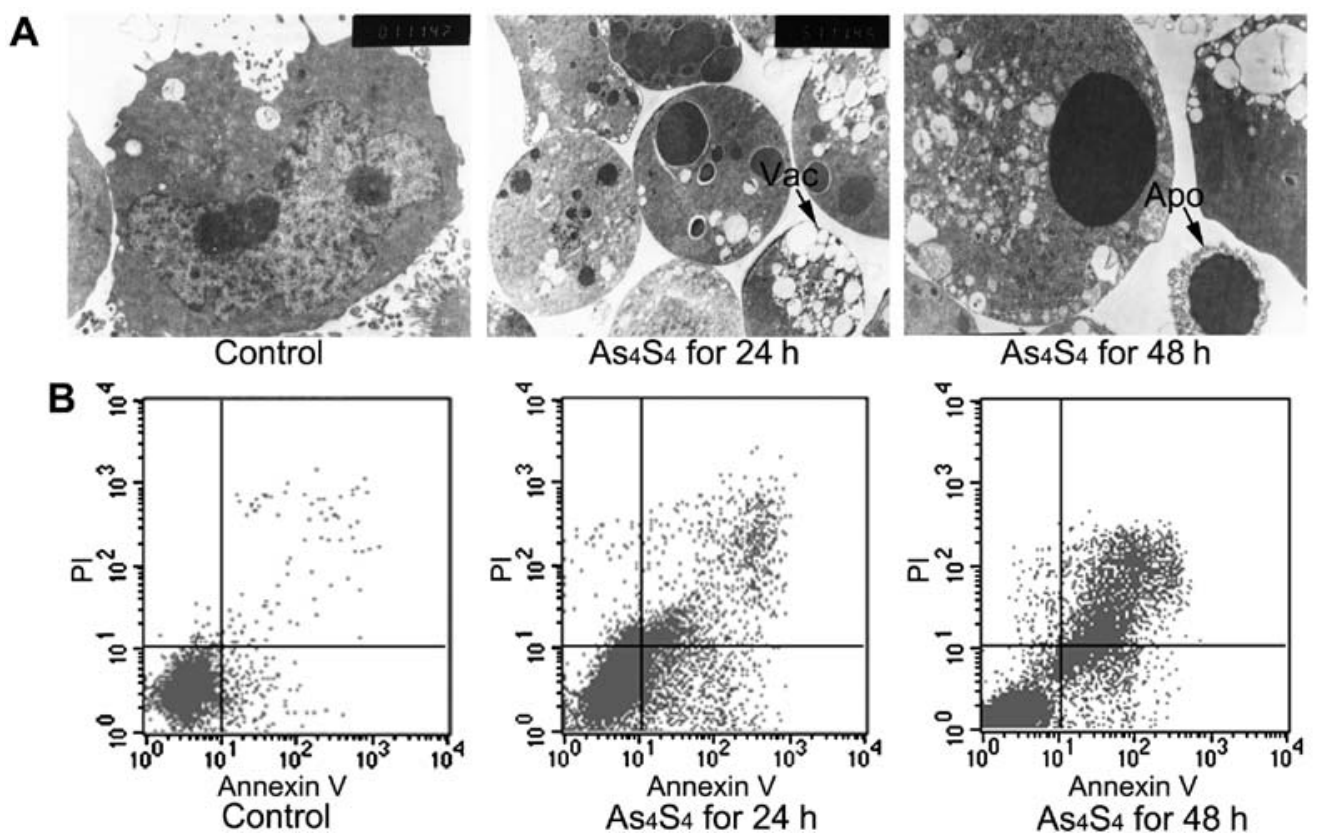

Figure 2. Evaluation of apoptosis of NB4-R1 cells induced by $\mathrm{As}_{4} \mathrm{~S}_{4}$. (A) Ultrastructural changes. Cells treated with As $\mathrm{S}_{4}$ for $24 \mathrm{~h}$ showed cytoplasmic vacuolization ( $\mathrm{Vac}$ ) and chromatin condensation, and cells treated with $\mathrm{As}_{4} \mathrm{~S}_{4}$ for $48 \mathrm{~h}$ showed nuclear fragmentation and formation of apoptotic bodies (Apo). Original magnification, $x 5000$. (B) Flow cytometric analysis of NB4-R1 cells apoptosis induced by $\mathrm{As}_{4} \mathrm{~S}_{4}$. The percentage of apoptotic cells $\left(\mathrm{Annexin} \mathrm{V}^{+}\right.$) was $2.7,33.4$ and $44.5 \%$ in control, $\mathrm{As}_{4} \mathrm{~S}_{4} 24$ and $48 \mathrm{~h}$, respectively.

analyzed by MALDI-TOF MS/MS. PMF and peptide amino acid sequence were analyzed for protein identification using the Mascot search program. Fig. 3C showed the PMF of spot U8 analyzed by MALDI-TOF-MS. spot U8 was identified as prohibitin (PHB) and the corresponding protein sequence is shown in Fig. 3D. The annotation of the 22 identified proteins is shown in Table I.

PHB was identified from the spot U8, which was upregulated induced by $\mathrm{As}_{4} \mathrm{~S}_{4}$. The increase in PHB protein was confirmed by western blot analysis. As shown in Fig. 3E, there was a 2.0- and 3.9-fold increase in PHB protein with $\mathrm{As}_{4} \mathrm{~S}_{4}$ for 24 and $48 \mathrm{~h}$, respectively. At mRNA level, PHB expression was increased by 1.8- and 3.2-fold with $\mathrm{As}_{4} \mathrm{~S}_{4}$ for 24 and $48 \mathrm{~h}$, respectively (Fig. 3F). The results indicate an upregulation of PHB gene expression at both mRNA and protein levels.

Generation of PHB-overexpression and PHB-knockdown NB4-R1 cells. To investigate whether PHB plays a functional role in NB4-R1 cell apoptosis, we used the PHB gene overexpressing vector (pEGFP-N1-3FLAG-PHB) to generate PHB-overexpression NB4-R1 cells (OE group). The PHB-overexpression efficiency was then validated by qRT-PCR and western blot analysis, respectively. Our results showed that PHB expression in OE group was increased by $67.8 \%$ at mRNA level and $45.8 \%$ at protein level (Fig. 4A and B). Similarly, the RNA interference vector (pGCSIL-GFP-PHB) of PHB gene was used to generate PHB-knockdown NB4-R1 cells (KD group). Our results showed that PHB expression was reduced by $83.5 \%$ at mRNA level and $89.7 \%$ at protein level, respectively (Fig. 4C and D).

PHB-overexpression promotes NB4-RI apoptosis and $P M L-R A R \alpha$ fusion protein degradation. Our results showed after $48 \mathrm{~h}$ of transfection, the percentages of apoptotic cells in
OE group was increased by 3.8 -fold in comparison with the parental NB4-R1 cells $(26.73 \pm 6.53$ vs. $7.11 \pm 1.02 \%, \mathrm{P}<0.01)$ (Fig. 5A), and the PML-RAR $\alpha$ fusion protein was reduced by 1.5 -fold in comparison with the control $(34.21 \pm 3.81$ vs. $51.31 \pm 8.55 \%, \mathrm{P}<0.01$ ) (Fig. 5B).

The response of the $\mathrm{OE}$ cells to $\mathrm{As}_{4} \mathrm{~S}_{4}$ was evaluated in comparison with parental NB4-R1 cells. OE cells showed an increase in $\mathrm{As}_{4} \mathrm{~S}_{4}$-induced apoptosis. With $\mathrm{As}_{4} \mathrm{~S}_{4}$ at the concentration of $25 \mu \mathrm{M}$ for $48 \mathrm{~h}$, the apoptotic cells in NB4-R1 and $\mathrm{OE}$ cells were $48.33 \pm 9.84$ and $58.71 \pm 11.74 \%$, respectively (Fig. 5A). PML-RAR $\alpha$ fusion protein was assessed by western blot analysis, and the results showed that $\mathrm{As}_{4} \mathrm{~S}_{4}$ treatment led to greater reduction of PML-RAR $\alpha$ protein in OE cells than that in NB4-R1 cells. In comparison with untreated NB4-R1 cells, $\mathrm{As}_{4} \mathrm{~S}_{4}$ treatment reduced PML-RAR $\alpha$ protein by 51.0 and $76.9 \%$ in NB4-R1 and OE cells, respectively (the grayscale ratios of PML-RAR $\alpha /$ GAPDH: $25.14 \pm 2.87$ and $11.86 \pm 2.99 \%$, $\mathrm{P}<0.05$ ) (Fig. 5B).

PHB-knockdown reduces $\mathrm{As}_{4} \mathrm{~S}_{4}$-induced apoptosis and degradation of PML-RAR $\alpha$ protein. PHB-knockdown NB4-R1 cells (KD) was evaluated in comparison with parental NB4-R1 cells. With no $\mathrm{As}_{4} \mathrm{~S}_{4}$ treatment, there was no significant difference in the baseline apoptotic cells between KD and NB4-R1 cells. Similarly, no significant difference was seen between KD and the NB4-R1 in the expression of PML-RAR $\alpha$ fusion proteins, as determined by PML-RAR $\alpha /$ GAPDH $(53.16 \pm 7.83$ vs. $49.78 \pm 1.89 \%$ ) (Fig. 6A and B).

The KD cells were then used to examine its response to $\mathrm{As}_{4} \mathrm{~S}_{4}$ treatment. $\mathrm{As}_{4} \mathrm{~S}_{4}$-induced apoptosis was evaluated with $\mathrm{As}_{4} \mathrm{~S}_{4}$ at the concentration of $25 \mu \mathrm{M}$ for $48 \mathrm{~h}$. In comparison with parental NB4-R1 cells, the KD showed a lesser degree of cellular apoptosis. The percentages of apoptotic cells in NB4-R1 and KD were determined to be $45.17 \pm 5.43$ and 


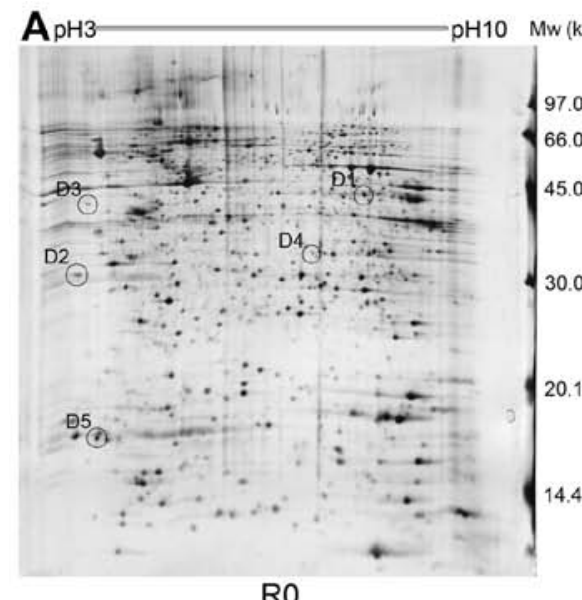

B

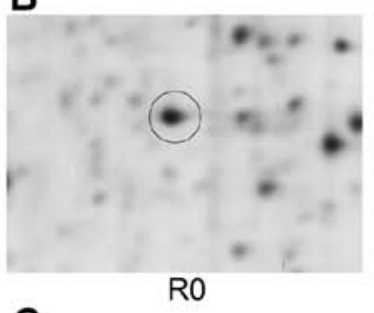

C

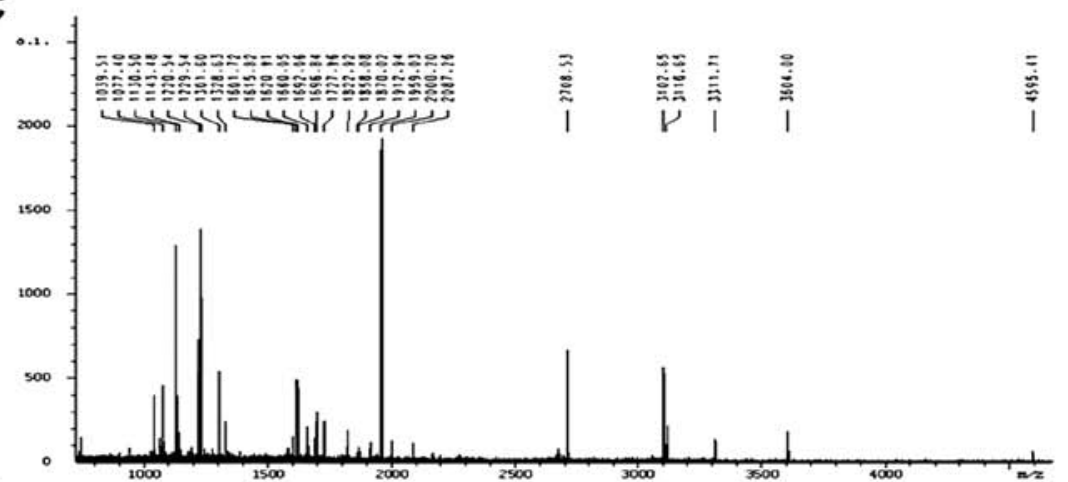

D

1 MAAKVFESIG KFGLALAVAG GVVNSALYNV DAGHRAVIFD RFRGVQDIVV

51 GEGTHFLIPW VQKLIIFDCR SRPRNVPVIT GSKDLQNVNI TLRILFRPVA

101 SQLPRIFTSI GEDYDERVLP SITTEILKSV VARFDAGELI TQRELVSRQV

151 SDDLTERAAT FGLILDDVSL THLTFGKEFT EAVEAKQVAQ QEAERARFVV

201 EKAEQQKKAA IISAEGDSKA AELIANSLAT AGDGLIELRK LEAAEDIAYQ

251 LSRSRNITYL PAGQSVLLQL PQ

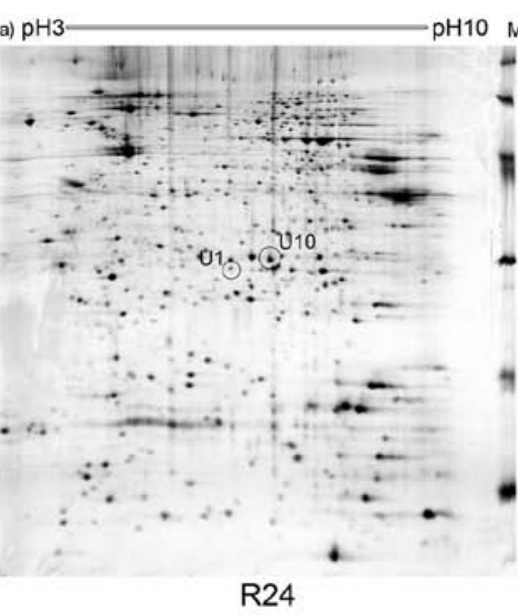

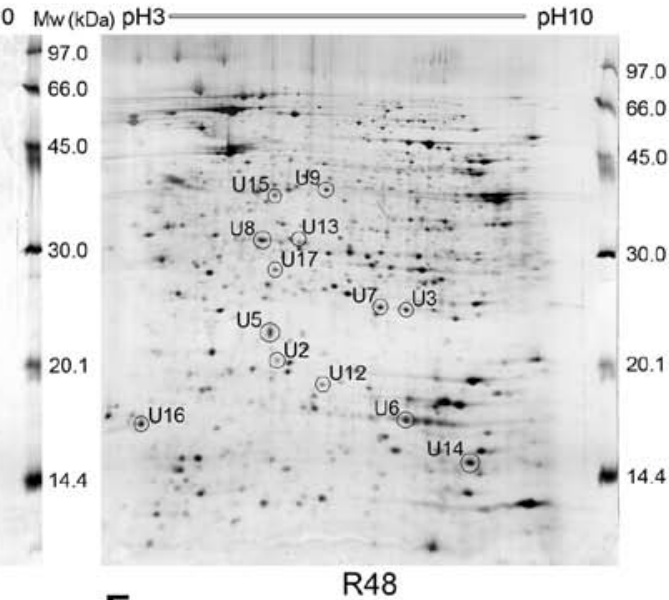

E

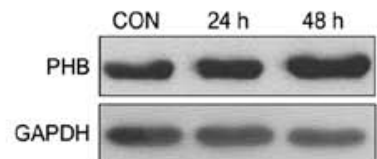

$\mathbf{F}$
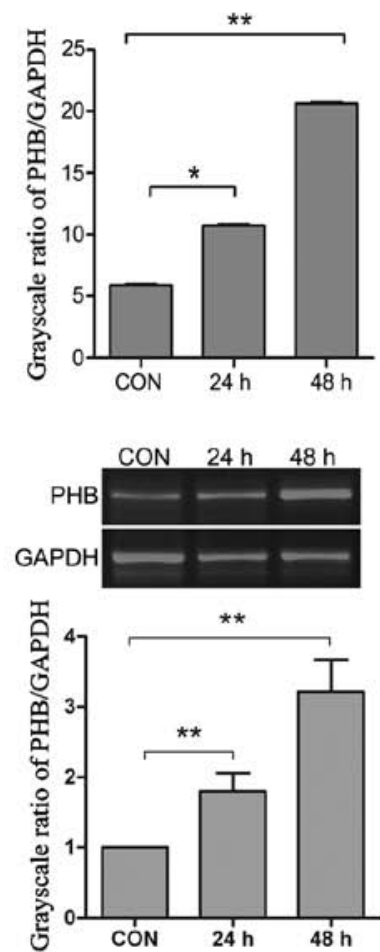

Figure 3. Selection and identification of upregulated PHB in NB4-R1 cells induced by $\mathrm{As}_{4} \mathrm{~S}_{4}$. (A) Representative silver-stained 2-DE maps of NB4-R1 cells untreated (R0), treated with $\mathrm{As}_{4} \mathrm{~S}_{4}$ for $24 \mathrm{~h}$ (R24) and $48 \mathrm{~h}$ (R48). Circles indicate the protein spots identified by MS or MS/MS. (B) The amplified image of differential expression protein spot U8 in R0, R24 and R48. Spot U8 showed increase in intensity at R24 and R48. (C) MALDI-TOF-MS analysis of differential protein spot U8. Spot U8 was identified as prohibitin (PHB) according to its MALDI-TOF-MS mass spectrum. (D) Protein sequence of PHB is shown and matched peptides are underlined. (E) Western blot analysis of PHB protein levels with PHB/GAPDH ratio as control for the comparison of the grayscale. (F) RT-PCR analysis of PHB mRNA levels. The grayscale ratio of PHB/GAPDH is provided for comparison. ${ }^{*} \mathrm{P}<0.05$; ${ }^{* *} \mathrm{P}<0.01$.

$22.16 \pm 3.92 \%$, respectively (Fig. 6A). Thus, there was a 2.0 -fold less $\mathrm{As}_{4} \mathrm{~S}_{4}$-induced apoptosis in $\mathrm{KD}$ than that in parental NB4-R1.

PML-RARa fusion protein of KD cells by western blot analysis. By using the grayscale ratios of PML-RAR $\alpha /$ GAPDH, the levels of PML-RAR $\alpha$ protein were determined to be $49.78 \pm 1.89 \%$ in the untreated cells, and $24.21 \pm 1.73$ and $37.95 \pm 7.79 \%$ in $\mathrm{As}_{4} \mathrm{~S}_{4}$-treated NB4-R1 and KD cells, respectively. Using the untreated cells as the baseline, $\mathrm{As}_{4} \mathrm{~S}_{4}$ lowered
PML-RAR $\alpha$ protein by 51.3 and $23.7 \%$ in NB4-R1 and KD cells, respectively (Fig. 6B). The results indicate that KD cells presented with a lesser degree of $\mathrm{As}_{4} \mathrm{~S}_{4}$-induced PML-RAR $\alpha$ degradation, $\sim 50 \%$ of that in parental NB4-R1 cells.

\section{Discussion}

Arsenic agents have been proved highly effective in the treatment of APL. It is particularly useful for relapsed/refractory APL with ATRA-resistance (18). $\mathrm{As}_{4} \mathrm{~S}_{4}$, is a new and prom- 

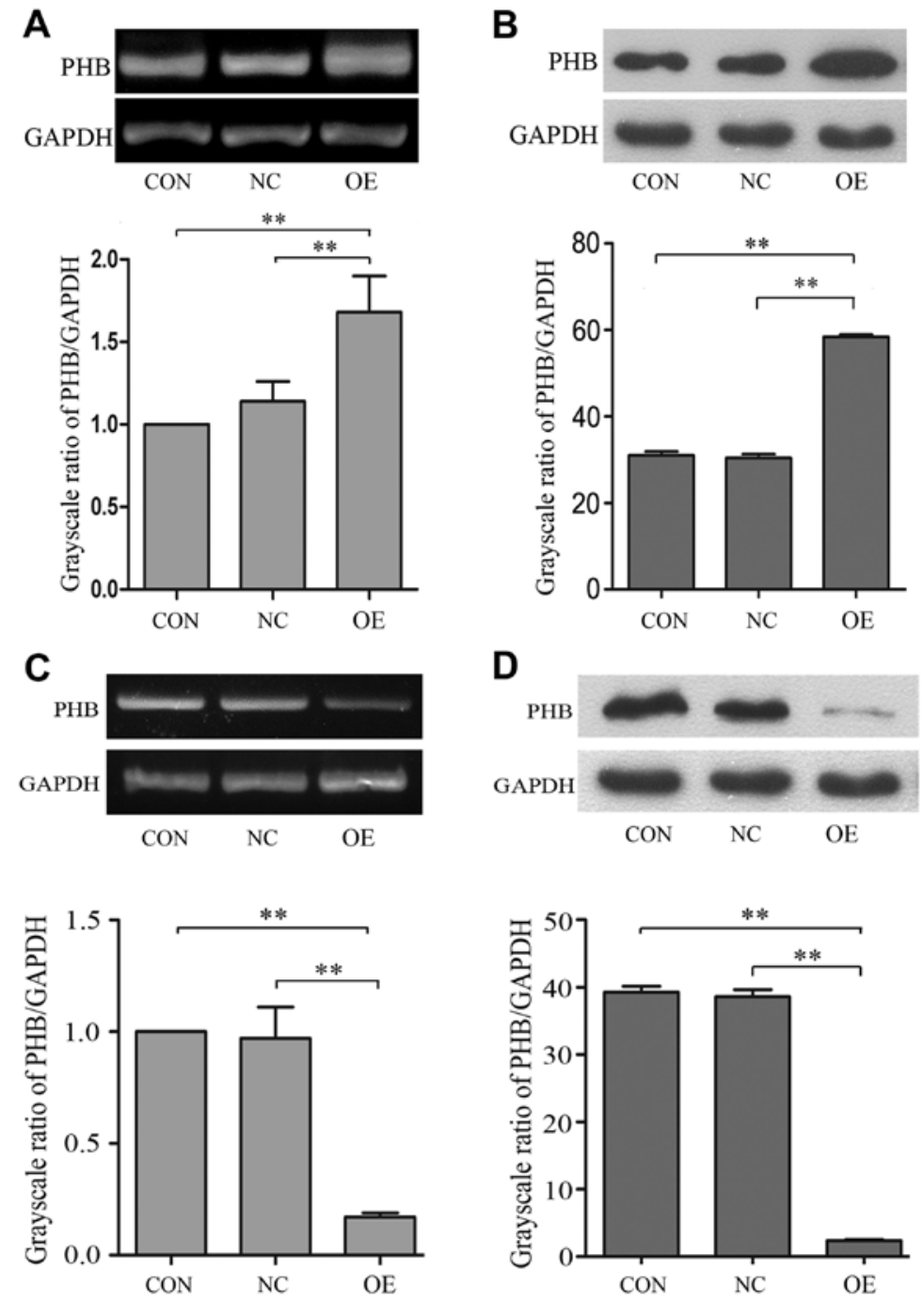

Figure 4. RT-PCR and western blot analysis of PHB overexpression and knockdown in NB4-R1 cells. (A) RT-PCR analysis of PHB overexpression. (B) Western blot analysis of PHB overexpression. (C) RT-PCR analysis of PHB knockdown. (D) Western blot analysis of PHB knockdown. ${ }^{* *} \mathrm{P}<0.01$. CON, control (NB4-R1 cells); NC, negative control (NB4-R1 cells transfected with empty vector); KD, PHB-knockdown NB4-R1 cells; OE, PHB-overexpressing NB4-R1 cells.

ising oral arsenic formulation. A multicenter study in China has shown that a complete remission (CR) rate of $99.1 \%$ and a disease-free survival (DFS) rate of $98.1 \%$ at 2 years were achieved in 108 APL cases treated with an oral $\mathrm{As}_{4} \mathrm{~S}_{4}$ combined with ATRA $(19,20)$. In the present study, we demonstrated that $\mathrm{As}_{4} \mathrm{~S}_{4}$ inhibited the growth and induced apoptosis of ATRAresistant NB4-R1 cells. The result is consistent with previous findings $(21,22)$. By using comparative proteomic approach, we identified PHB was significantly upregulated during $\mathrm{As}_{4} \mathrm{~S}_{4^{-}}$ induced NB4-R1 apoptosis. As PHB is of particular interest, further experiments were performed to modulate the gene expression, either PHB overexpression or PHB knockdown. The results with modulation of PHB expression implicate its activity in promoting $\mathrm{As}_{4} \mathrm{~S}_{4}$-induced apoptosis.

PHB was selected in this study for its diverse roles in the regulation of proliferation, apoptosis and gene transcription (23-27). PHB proteins have been found to localize in the mitochondria, nucleus and plasma membrane of mammalian cells. PHB is implicated in diverse cellular processes, including mitochondrial biogenesis, cell death and replicative senescence. A functional role for PHB as a regulator of tran- scription has been shown for its interactions with p53, E2F and $\mathrm{Rb}$ (28-30). PHB has been associated with various types of cancer. The role of PHB in cancer cell proliferation or tumor suppression is considered controversial. PHB was shown to be necessary for the activation of C-Raf by the oncogene Ras in HeLa cells (31). However, many reports have shown evidence that PHB has antitumorigenic activity in prostate, gastric and ovarian cancer (32-35). PHB overexpression was shown to result in the inhibition of prostate cancer cell growth and the knockdown of PHB by siRNA accelerates tumor growth (33).

In the present study, stable clones of KD (PHB-knockdown NB4-R1 cells) and OE (PHB-overexpression NB4-R1 cells) were established and used to determine the cellular response to $\mathrm{As}_{4} \mathrm{~S}_{4}$. The results showed that PHB overexpression enhanced apoptosis of NB4-R1 cells, and reduction of PML-RAR $\alpha$ fusion protein. Although PHB knockdown had no significant effect on baseline apoptosis and PML-RAR $\alpha$ fusion protein, a downregulation of PHB was associated with an attenuated apoptosis and lesser reduction of PML-RAR $\alpha$ protein in the cells treated with $\mathrm{As}_{4} \mathrm{~S}_{4}$. These results strongly support that PHB has antitumorigenic activity. 
A
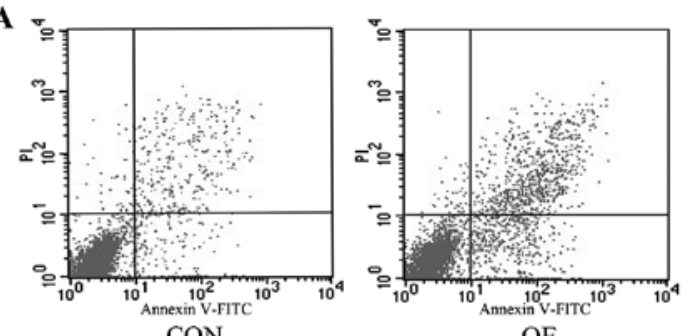

$\mathrm{CON}$
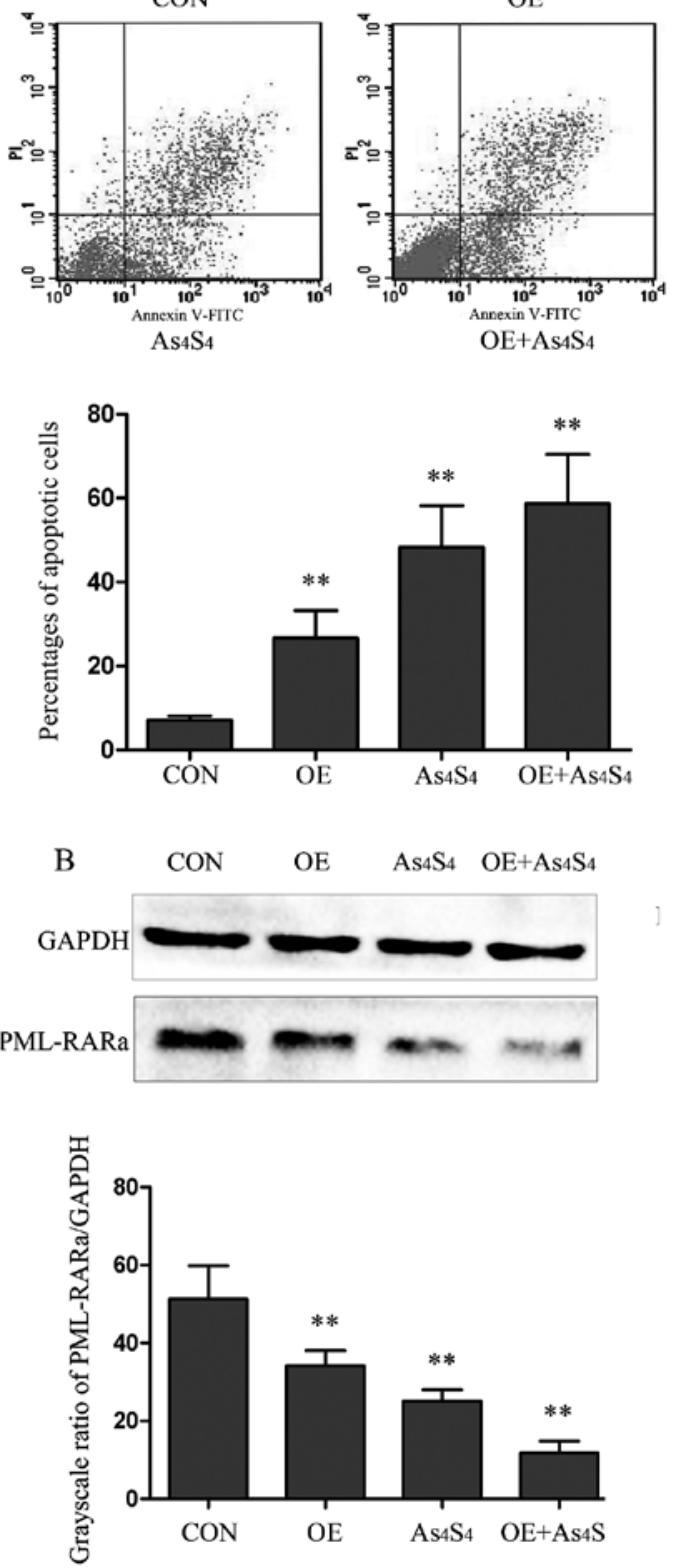

Figure 5. Effect of PHB overexpression on the apoptosis and the expression of PML-RAR $\alpha$ protein in NB4-R1 cells induced by $\mathrm{As}_{4} \mathrm{~S}_{4}$. (A) FCM analysis of the apoptosis of the control NB4-R1 cells, OE cells, NB4-R1 cells treated by $\mathrm{As}_{4} \mathrm{~S}_{4}$ and $\mathrm{OE}$ cells treated by $\mathrm{As}_{4} \mathrm{~S}_{4}$, respectively. (B) Western blot analysis of the expression of PML-RAR $\alpha$ fusion protein. ${ }^{* *} \mathrm{P}<0.01$. CON, control (NB4-R1 cells untreated); OE, PHB-overexpression NB4-R1 cells; $\mathrm{As}_{4} \mathrm{~S}_{4}$ NB4-R1 cells treated by $\mathrm{As}_{4} \mathrm{~S}_{4} ; \mathrm{OE}+\mathrm{As}_{4} \mathrm{~S}_{4}$ : PHB-overexpressing NB4-R1 cells treated by $\mathrm{As}_{4} \mathrm{~S}_{4}$.

The effects of PHB on cellular processes may be due to its subcellular localization in different type cells. The subcellular localization of PHB has been shown to affect cell fate, specifically apoptosis (36). PHB has been shown with an increased
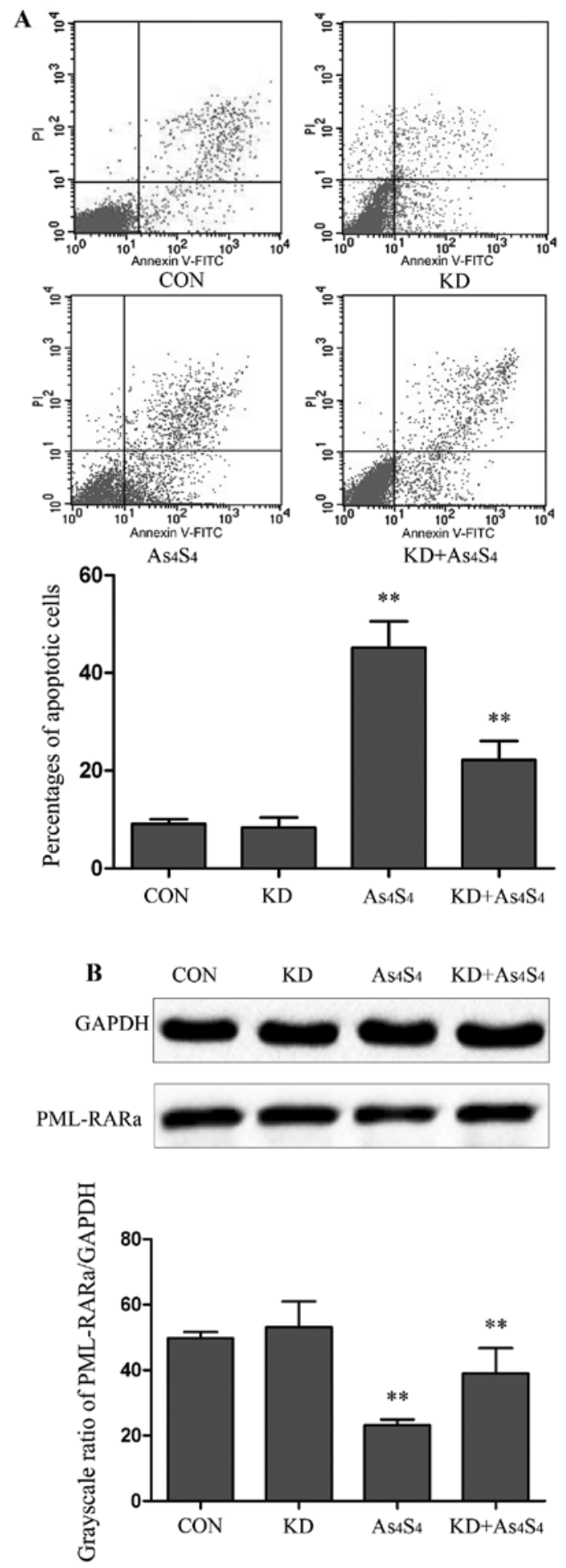

Figure 6. Effect of PHB knockdown on the apoptosis and the expression of PML-RAR $\alpha$ protein in NB4-R1 cells induced by $\mathrm{As}_{4} \mathrm{~S}_{4}$. (A) FCM analysis of the apoptosis of NB4-R1 and KD cells untreated, and treated by $\mathrm{As}_{4} \mathrm{~S}_{4}$, respectively. (B) Western blot analysis of the expression of PML-RAR $\alpha$ fusion protein. The grayscale ratio of PML-RAR $\alpha /$ GAPDH is provided for comparison. ${ }^{* *} \mathrm{P}<0.01$. CON, control (NB4-R1 cells untreated); KD, PHBknockdown NB4-R1 cells; $\mathrm{As}_{4} \mathrm{~S}_{4}$ : NB4-R1 cells treated by $\mathrm{As}_{4} \mathrm{~S}_{4} ; \mathrm{KD}+\mathrm{As}_{4} \mathrm{~S}_{4}$ : PHB-knockdown NB4-R1 cells treated by $\mathrm{As}_{4} \mathrm{~S}_{4}$.

level on the cell membrane that facilitates tumorigenesis through its interaction with c-Raf induced by the Ras oncogene $(37,38)$, whereas increased levels of PHB in the nucleus induce apoptosis by increasing the transcriptional activity of 
p53 and its translocation to the cytoplasm (39). We have found the increased levels of PHB, either modulated by $\mathrm{As}_{4} \mathrm{~S}_{4}$ or by PHB overexpression vectors, in the nucleus locations of APL cells.

The PML-RAR $\alpha$ fusion protein is the key molecule that drives APL cells. This fusion protein also serves as the therapeutic target of ATRA and arsenic agents (40). While ATRA induces APL to undergo differentiation by targeting the RAR $\alpha$ moiety, arsenic agents induce apoptosis through SUMO-1-mediated degradation of the PML moiety of the fusion protein (41). However, other molecules involved in the process remain to be identified. In this study, we showed a close relationship of upregulation of PHB with reduction of PML-RAR $\alpha$ during $\mathrm{As}_{4} \mathrm{~S}_{4}$-induced apoptosis. Consistently, PHB knockdown experiments showed a reduced degradation of PML-RAR $\alpha$ protein. These results indicate that PHB is involved in the APL cell apoptosis. However, the biochemical pathway of PHB activity in relation to PML-RAR $\alpha$ remains the subject of investigations.

In conclusion, PHB was identified among the upregulated proteins associated with $\mathrm{As}_{4} \mathrm{~S}_{4}$-induced apoptosis of NB4-R1 cells. The experiments with modulation of PHB expression indicate that PHB overexpression enhances apoptosis and degradation of PML-RAR $\alpha$ fusion protein, and consistently PHB knockdown attenuated the cellular response to $\mathrm{As}_{4} \mathrm{~S}_{4}$ treatment.

\section{Acknowledgements}

The present study is supported by a research grant from the Natural Science Foundation of China (NSFC, grant no. 30701133), the Shaanxi Province Science and Technology Development Fund (SPSTDF, grant no. 2012KTCL03-12). The authors thank Dr Qunling Zhang from Shanghai Institute of Hematology for providing the NB4-R1 cell line; Dr Xinyang Wang from the First Affiliated Hospital, Xi'an Jiaotong University for their technological assistance; and Dr Byron Song from Univerity of Tronto, Ontario, Canada for critically reading the manuscript.

\section{References}

1. Sahin U, Lallemand-Breitenbach V and de Thé H: PML nuclear bodies: Regulation, function and therapeutic perspectives. J Pathol 234: 289-291, 2014.

2. Rabellino A, Carter B, Konstantinidou G, Wu SY, Rimessi A, Byers LA, Heymach JV, Girard L, Chiang CM, Teruya-Feldstein J, et al: The SUMO E3-ligase PIAS1 regulates the tumor suppressor PML and its oncogenic counterpart PML-RARA. Cancer Res 72: 2275-2284, 2012.

3. Guo Y, Dolinko AV, Chinyengetere F, Stanton B, Bomberger JM, Demidenko E, Zhou DC, Gallagher R, Ma T, Galimberti F, et al: Blockade of the ubiquitin protease UBP43 destabilizes transcription factor PML/RAR $\alpha$ and inhibits the growth of acute promyelocytic leukemia. Cancer Res 70: 9875-9885, 2010.

4. de Thé H and Chen Z: Acute promyelocytic leukaemia: Novel insights into the mechanisms of cure. Nat Rev Cancer 10 775-783, 2010.

5. Wang ZY and Chen Z: Acute promyelocytic leukemia: From highly fatal to highly curable. Blood 111: 2505-2515, 2008.

6. Tomita A, Kiyoi $\mathrm{H}$ and Naoe T: Mechanisms of action and resistance to all-trans retinoic acid (ATRA) and arsenic trioxide $\left(\mathrm{As}_{2} \mathrm{O}_{3}\right)$ in acute promyelocytic leukemia. Int $\mathrm{J}$ Hematol 97: 717-725, 2013
7. Mathews V, George B, Lakshmi KM, Viswabandya A, Bajel A, Balasubramanian P, Shaji RV, Srivastava VM, Srivastava A and Chandy M: Single-agent arsenic trioxide in the treatment of newly diagnosed acute promyelocytic leukemia: Durable remissions with minimal toxicity. Blood 107: 2627-2632, 2006.

8. Lengfelder E, Hofmann WK and Nowak D: Impact of arsenic trioxide in the treatment of acute promyelocytic leukemia. Leukemia 26: 433-442, 2012.

9. Wu J, Shao Y, Liu J, Chen G and Ho PC: The medicinal use of realgar $\left(\mathrm{As}_{4} \mathrm{~S}_{4}\right)$ and its recent development as an anticancer agent. J Ethnopharmacol 135: 595-602, 2011.

10. Lengfelder E, Hofmann WK and Nowak D: Treatment of acute promyelocytic leukemia with arsenic trioxide: Clinical results and open questions. Expert Rev Anticancer Ther 13: 1035-1043, 2013.

11. van Meerloo J, Kaspers GJ and Cloos J: Cell sensitivity assays: the MTT assay. Methods Mol Biol 731: 237-245, 2011.

12. Qian X, Dong H, Hu X, Tian H, Guo L, Shen Q, Gao X and Yao W: Analysis of the interferences in quantitation of a sitespecifically PEGylated exendin- 4 analog by the Bradford method. Anal Biochem 465: 50-52, 2014.

13. Rabilloud $\mathrm{T}$ and Lelong C: Two-dimensional gel electrophoresis in proteomics: A tutorial. J Proteomics 74: 1829-1841, 2011.

14. Dupont FM, Vensel WH, Tanaka CK, Hurkman WJ and Altenbach SB: Deciphering the complexities of the wheat flour proteome using quantitative two-dimensional electrophoresis, three proteases and tandem mass spectrometry. Proteome Sci 9: $10,2011$.

15. Lelong $\mathrm{C}$, Chevallet $\mathrm{M}$, Luche $\mathrm{S}$ and Rabilloud T: Silver staining of proteins in 2DE gels. Methods Mol Biol 519: 339-350, 2009.

16. Granvogl B, Plöscher M and Eichacker LA: Sample preparation by in-gel digestion for mass spectrometry-based proteomics. Anal Bioanal Chem 389: 991-1002, 2007.

17. Liu $\mathrm{Y}, \mathrm{He} \mathrm{P}$, Zhang $\mathrm{M}$ and $\mathrm{Wu} \mathrm{D}$ : Lentiviral vector-mediated RNA interference targeted against prohibitin inhibits apoptosis of the retinoic acid-resistant acute promyelocytic leukemia cell line NB4-R1. Mol Med Rep 6: 1288-1292, 2012.

18. Lu DP, Qiu JY, Jiang B, Wang Q, Liu KY, Liu YR and Chen SS: Tetra-arsenic tetra-sulfide for the treatment of acute promyelocytic leukemia: A pilot report. Blood 99: 3136-3143, 2002.

19. Zhu HH, Wu DP, Jin J, Li JY, Ma J, Wang JX, Jiang H, Chen SJ and Huang XJ: Oral tetra-arsenic tetra-sulfide formula versus intravenous arsenic trioxide as first-line treatment of acute promyelocytic leukemia: A multicenter randomized controlled trial. J Clin Oncol 31: 4215-4221, 2013.

20. Zhu HH and Huang XJ: Oral arsenic and retinoic acid for nonhigh-risk acute promyelocytic leukemia. N Engl J Med 371: 2239-2241, 2014

21. Wang L, Zhou GB, Liu P, Song JH, Liang Y, Yan XJ, Xu F, Wang BS, Mao JH, Shen ZX, et al: Dissection of mechanisms of Chinese medicinal formula Realgar-Indigo naturalis as an effective treatment for promyelocytic leukemia. Proc Natl Acad Sci USA 105: 4826-4831, 2008.

22. Chen S, Fang Y, Ma L, Liu S and Li X: Realgar-induced apoptosis and differentiation in all-trans retinoic acid (ATRA)-sensitive NB4 and ATRA-resistant MR2 cells. Int J Oncol 40: 1089-1096, 2012.

23. Zhou TB and Qin YH: Signaling pathways of prohibitin and its role in diseases. J Recept Signal Transduct Res 33: 28-36, 2013.

24. Rossi L, Bonuccelli L, Iacopetti P, Evangelista M, Ghezzani C, Tana L and Salvetti A: Prohibitin 2 regulates cell proliferation and mitochondrial cristae morphogenesis in planarian stem cells. Stem Cell Rev 10: 871-887, 2014.

25. Liu YH, Peck K and Lin JY: Involvement of prohibitin upregulation in abrin-triggered apoptosis. Evid Based Complement Alternat Med 2012: 605154, 2012.

26. Puppin C, Passon N, Franzoni A, Russo D and Damante G: Histone deacetylase inhibitors control the transcription and alternative splicing of prohibitin in thyroid tumor cells. Oncol Rep 25: 393-397, 2011

27. Joshi B, Ko D, Ordonez-Ercan D and Chellappan SP: A putative coiled-coil domain of prohibitin is sufficient to repress E2F1mediated transcription and induce apoptosis. Biochem Biophys Res Commun 312: 459-466, 2003.

28. Chander H, Halpern M, Resnick-Silverman L, Manfredi JJ and Germain D: Skp2B attenuates p53 function by inhibiting prohibitin. EMBO Rep 11: 220-225, 2010. 
29. Joshi B, Rastogi S, Morris M, Carastro LM, DeCook C, Seto E and Chellappan SP: Differential regulation of human YY1 and caspase 7 promoters by prohibitin through E2F1 and p53 binding sites. Biochem J 401: 155-166, 2007.

30. Wang S, Fusaro G, Padmanabhan J and Chellappan SP: Prohibitin co-localizes with $\mathrm{Rb}$ in the nucleus and recruits $\mathrm{N}-\mathrm{CoR}$ and HDAC1 for transcriptional repression. Oncogene 21: 8388-8396, 2002.

31. Rajalingam K, Wunder C, Brinkmann V, Churin Y, Hekman M, Sievers C, Rapp UR and Rudel T: Prohibitin is required for Ras-induced Raf-MEK-ERK activation and epithelial cell migration. Nat Cell Biol 7: 837-843, 2005.

32. Wang S and Faller DV: Roles of prohibitin in growth control and tumor suppression in human cancers. Transl Oncogenomics 3: 23-37, 2008.

33. Dart DA, Spencer-Dene B, Gamble SC, Waxman J and Bevan CL: Manipulating prohibitin levels provides evidence for an in vivo role in androgen regulation of prostate tumours. Endocr Relat Cancer 16: 1157-1169, 2009.

34. Zhang Y, Chen Y, Qu C, Zhou M,Ni Q and Xu L: siRNA targeting prohibitins inhibits proliferation and promotes apoptosis of gastric carcinoma cell line SGC7901 in vitro and in vivo. Cell Mol Biol (Noisy-le-grand) 60: 26-32, 2014

35. Jia L, Ren JM, Wang YY, Zheng Y, Zhang H, Zhang Q, Kong BH and Zheng WX: Inhibitory role of prohibitin in human ovarian epithelial cancer. Int J Clin Exp Pathol 7: 2247-2255, 2014.
36. Theiss AL and Sitaraman SV: The role and therapeutic potential of prohibitin in disease. Biochim Biophys Acta 1813: 1137-1143, 2011.

37. Rajalingam $\mathrm{K}$ and Rudel $\mathrm{T}$ : Ras-Raf signaling needs prohibitin. Cell Cycle 4: 1503-1505, 2005.

38. Chowdhury I, Thompson WE and Thomas K: Prohibitins role in cellular survival through Ras-Raf-MEK-ERK pathway. J Cell Physiol 229: 998-1004, 2014

39. Song W, Tian L, Li SS, Shen DY and Chen QX: The aberrant expression and localization of prohibitin during apoptosis of human cholangiocarcinoma Mz-ChA-1 cells. FEBS Lett 588: 422-428, 2014.

40. Zhou GB, Zhang J, Wang ZY, Chen SJ and Chen Z: Treatment of acute promyelocytic leukaemia with all-trans retinoic acid and arsenic trioxide: A paradigm of synergistic molecular targeting therapy. Philos Trans R Soc Lond B Biol Sci 362: 959-971, 2007.

41. Shinagawa K: All-trans retinoic acid and arsenic trioxide: Their molecular mechanisms of action and updated clinical progress in APL therapy. Rinsho Ketsueki 52: 469-483, 2011 (In Japanese). 